\title{
Determinant Factors Affecting the Web-based Training Acceptance by Health Students, Applying UTAUT Model
}

\author{
https://doi.org/10.3991/ijet.v12i10.7258 \\ Asgar Sattari, Mohammadhiwa Abdekhoda $\left({ }^{\varpi}\right)$,Vahide Zarea Gavgani \\ Tabriz University of Medical Sciences, Tabriz, Iran \\ hiwaabdekhoda@gmail.com
}

\begin{abstract}
Nowadays Web-based training (WBT) is the most advanced training methods. With the increasing use of modern methods of training in universities necessity of identification of the factors influencing the acceptance of web-based training becomes more obvious. This study examines the factors influencing the acceptance of web-based training by students. This study was cross-sectional survey and conducted from August to December 2016. As sample, 229 students of Tabriz University of Medical Sciences (TUOMS) were asked to participate in this study and fill the corresponding questionnaires. The unified theory of acceptance and use of technology (UTAUT) was applied to investigate and explain the acceptance of E-learning. The data were analyzed by SPSS v.16. Findings revealed that the web- based training acceptance was directly influenced by performance expectancy, effort expectancy, facilitated condition, and attitude toward technology, self-efficacy, and anxiety. In contrast the impact of the social influences hadn't been observed on behavior indentation. The findings indicated that UTAUT model explains about $58 \%$ of the variance for adoption of WBT. The study not only provides an indicator of students' acceptance of E-learning, but also recognizes the important factors that would contribute to its successful use. The simulating or disappointing factors effecting use of the E-learning systems in university have been understood in a well-organized way according to the received results. Decision makers should apply these conclusions to improve strategies to align users' expectations with use of technology use learning.
\end{abstract}

Keywords-Web based training, Electronic learning, Health education, Student, Unified Theory of Acceptance and Use of Technology (UTAUT)

\section{Introduction}

As we are walking into the age of information, one of the concepts influenced, is education and its related issues, being shifted from old, paper-based methods to up to date, web-based ones (Sohrabiyourtchi et al. 2010). So in order not to fall behind from today's education, linked services need to be provided. Currently, it's one of the most fundamental issues in science education training centers, that how they prepare students for the society that is increasingly gets informational (Njenga and Fourie 2010). 
In an informational society to achieve a high level of ownership and knowledge management will be one of the important competitive advantages (Babaei 1389, Song 2010). E-learning is rooted phenomenon known as "distance learning". Printed based learning to TV learning and interactive technology are examples and history of "distance learning" (Sherry 1996). In a broad sense E-learning is learning through electronic media such as internet, intranet, extranet, hypermedia/hypertext, and so on (Govindasamy 2001). And also combinations of technology services and products that creates a coherent institutional environment. With online learning as an E-learning, students can have access to education courses in anywhere and anytime that internet is available (Cloete and Kotzé 2002).

Management systems that are used for online education allows synchronous and asynchronous communication both between students and teachers. In synchronous learning, it's possible that teacher and learner are met simultaneously in chat rooms, but in synchronous students ask their question and the teacher replies to their questions later (Rosenberg 2001).

Web Based Training (WBT) is also being common among societies, due to its privileges such as scalability (Clarke and Hermens 2001), availability (Herrington, Reeves, and Oliver 2009, Andone and Sireteanu 2009), high efficiency in teaching and learning, and so on (Brown 2014, Luthans et al. 2007, Asheim, Coenen, and Vang 2007). On the other hand, environmental factors (kheirandish 1393), lack of knowledge in using (WBT) (Hamburg and O'Brien 2014), insufficient funding (Mansour 2006), ethical issues (Anthony, Clarke, and Anderson 2000), and technophobia (Weil and Rosen 1995) are challenges faced in E-learning.

E-learning in Iranian Medical University is performed via Education Development center (EDC). EDC is educational and research center founded by The Ministry and Education in 1369 (1990), in order to improve the quality of education in medical universities.

\section{$2 \quad$ UTAUT model}

As a result of continually evolving technologies, technology acceptance research develops repeatedly. Models and theories pointing technology acceptance, adoption, and usage have progressed along the contribution of two major disciplines.

Among known models of technology acceptance, Technology Acceptance Model (TAM), Theory of Reasoned action (TRA) and the Theory of Planned Behavior (TPB) have been of the most use in the field of information technology acceptance (Liker and Sindi 1997, Gillenson and Sherrell 2002, Adams, Nelson, and Todd 1992, Abdekhoda et al. 2014, Abdekhoda et al. 2015).

Technology Acceptance Model (TAM): this is a modification of TRA mentioned by Davis in his PHD dissertation. TAM is a technology-based model to affirm that the tendency to accept a technology is a good anticipator to its factual usage (Hong, Thong, and Tam 2006, Abdekhoda, Ahmadi, et al. 2016).

Theory of Reasoned action (TRA): this theory was intentioned by Fishbein and Ajzen to anticipate and explain behavior and according to this theory individual act 


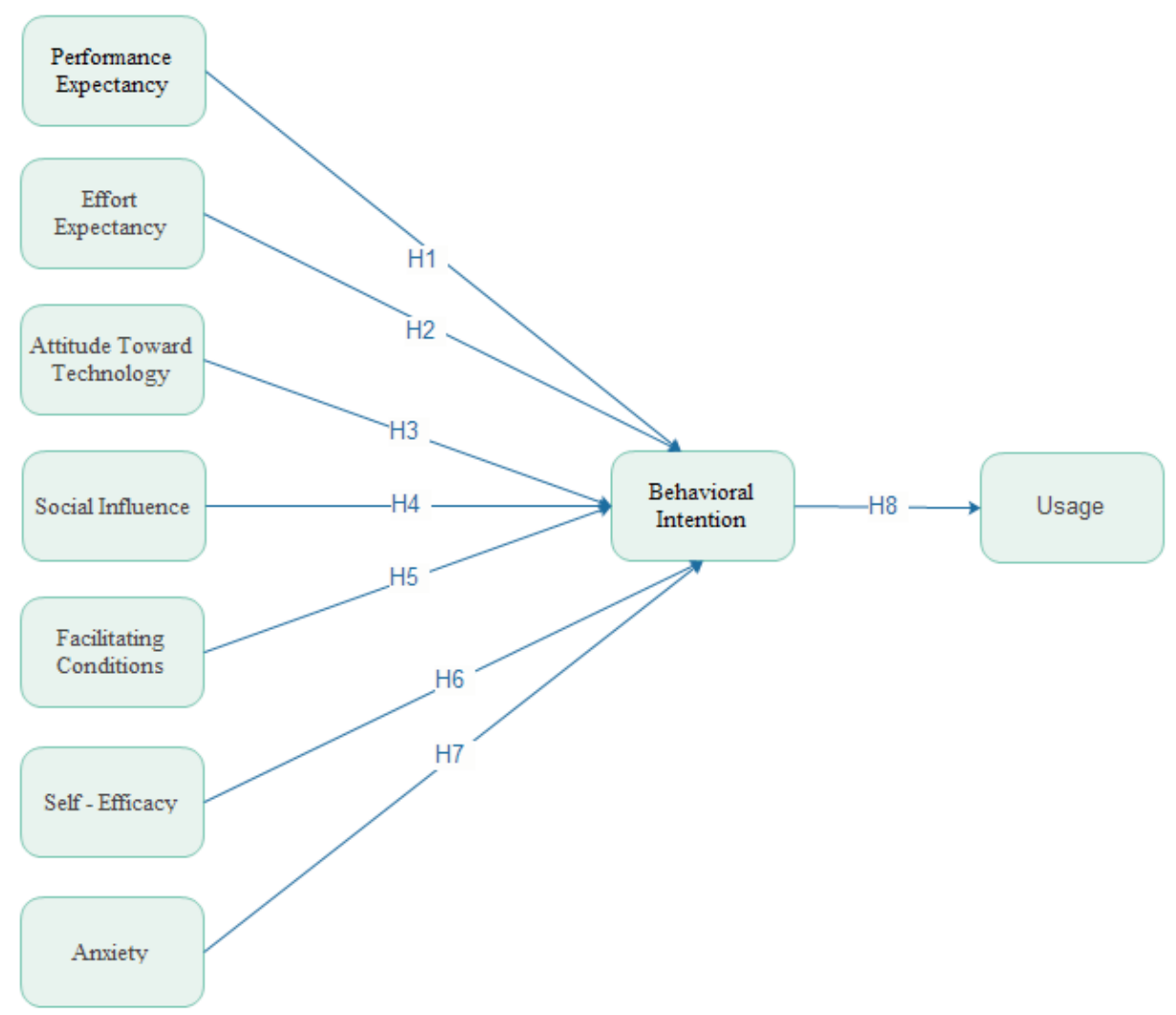

Fig. 1. The proposed conceptual model for E-learning acceptance by students, based on UTAUT.

reasonably. They collect and orderly assess all the accessible information about target behavior. They also consider effect and result of actions, then they decide whether to act or not, according to their logic (Pikkarainen et al. 2004).

Theory of Planned Behavior (TPB): in this theory, presented by Ajzen, motivating factors have been used to forecast a special behavior, and tendency being a reflection of personal motivation for a special behavior is assumed according to the mentioned theory (Nigg, Lippke, and Maddock 2009). Tendency to behavior is the fruit of three factors: attitude, psychic norm and psychic understanding of behavior control (Chen, Fan, and Farn 2007).

Different factors effect adoption and use of information technologies in Elearning(AMIRINASAB and MEHRAZIN 2014), and as one of the comprehensive models, Integrated Unified Theory of Acceptance and Use of Technology (UTAUT) is the most prominent for product acceptance analysis(Venkatesh et al. 2003), Which is an individual compiled from eight models (TRA ${ }^{1}, \mathrm{TAM}^{2}, \mathrm{MM}^{3}, \mathrm{TPB}^{4}, \mathrm{C}-\mathrm{TAM}-$

\footnotetext{
${ }^{1}$ Theory of Reasoned Action

2 Technology Acceptance Model

${ }^{3}$ Motivational Model
} 
$\mathrm{TPB}^{5}, \mathrm{MPCU}^{6}, \mathrm{IDT}^{7}$, and $\mathrm{SCT}^{8}$ ) (Venkatesh et al. 2003). Mentioned theory could predict the acceptance of an information system in approximately $70 \%$ of cases, while TAM can only reach up to a maximum of $40 \%$ (Marchewka, Liu, and Kostiwa 2007).

For this study four constructs will play an impressive role as direct determinants of user acceptance and usage behavior (see Figure 1):

1. Performance expectancy: "the degree to which an individual believes that using the system will help him or her to attain gains in job performance" (Venkatesh et al. 2003);

2. Effort expectancy: "the degree of ease associated with the use of the system" (Venkatesh et al. 2003);

3. Social influence: "the degree to which an individual perceives that it is important others believe that he or she should use the new system" (Venkatesh et al. 2003);

4. Facilitating conditions: "the degree to which an individual believes that an organizational and technical infrastructure exists to support use of the system"(Venkatesh et al. 2003).

This model also found 4 moderators affecting the determinants: gender, age, experience and voluntaries of use; it also contains use of modern technology way more than previous models (Baron and Kenny 1986, Venkatesh et al. 2003).

\section{Research hypotheses}

In this study, we proposed eight hypotheses, which are as follows:

1. Performance Expectancy (PE) will have a direct effect on the students' Behavioral Intentions (BI) to use E-learning.

2. Effort Expectancy (EE) will have a direct effect on the students' Behavioral Intentions (BI) to use E-learning.

3. Social Influence (SI) will have a direct effect on the students' Behavioral Intentions (BI) to use E-learning.

4. Facilitating Conditions (FC) will have a direct effect on the students' Behavioral Intentions (BI) to use E-learning.

5. Attitude Toward Technology (ATT) will have a direct effect on the students' Behavioral Intentions (BI) to use E-learning.

6. Self-Efficacy (SE) will have a direct effect on the students' Behavioral Intentions (BI) to use E-learning.

7. Anxiety will have a direct effect on the students' Behavioral Intentions (BI) to use E-learning.

8. Behavioral Intentions (BI) will have a direct effect on the students' Usage to use Elearning.

\footnotetext{
${ }^{4}$ Theory of Planned Behavior

5 combined TAM and TPB

${ }^{6}$ Model of PC Utilization

7 Innovation Diffusion Theory

${ }^{8}$ Social Cognitive Theory
} 


\section{$4 \quad$ Method}

In this study, UTAUT have been used to study acceptance and use of E-learning applied by Tabriz University of Medical Sciences' (TUOMS) students. The present study used case study as a methodology and adopted quantitative methods of data collection to explore the factors that impact the acceptance of e-learning in Tabriz University of Medical Sciences TUOMS, and conducted from August to December 2016. The target population was TUOMS that their students have used the studies center and development (EDC) of Tabriz University of Medical Science's E-learning $(\mathrm{n}=600)$. Due to the exploratory nature of this study and the fact that Convenience sampling is confirmed, it has been used (Zikmund 2003).

Data collecting instrument was questionnaire, which was based on existing tested and verified instruments to ensure content validity (Liu 2013, Abdekhoda, Dehnad, et al. 2016, Tan 2013).The questionnaires were physically distributed to the participant $(n=239)$ during the beginning of the first semester of 2016/2017 in TUOMS.

The questionnaires used in this study were arranged into two main sections, which the first part contained four demographic characteristics, which are gender, age, faculty, and degree. The next part included 8 items and 29 questions involving factors affecting adoption of e-learning based on the research model. We used a Likert-type 5-point scale: "1) strongly disagree, 2) disagree, 3) no idea, 4) agree, and 5) strongly agree". Validity of the questionnaire content was measured by content validity index and content validity ratio; then confirmed by existing texts and specialists' opinion.

Literature recommends all applied factors should be more than 0.50 and significant (Hair et al. 1998). On the respective constructs, the standardized factors applied to all 33 items were significant $(\mathrm{p}<0.01)$ and their value were greater than that 0.7 . Consequently, all factors in aforementioned model had satisfactory convergent validity.

After gathering and due to analyzing them, Data were entered in the SPSS software program, and the descriptive statistics (mean, median and mean) and inferential statistics (Spearman correlation coefficient and regression) were used, that have been used to answer in questions. SPSS was used for analyzing data, as UTAUT model was used for questionnaires, and analyzing data was followed by this procedure.

\section{$5 \quad$ Result}

This study was conducted with a sample of 239 students' who use E-learning in Tabriz University of Medical Sciences (TUOMS). The hypotheses are tested by the Statistical Package for Social Sciences (SPSS) software. The majority of the respondents' age varied between 17 and $27(83.4 \%)$. As seen in table 1, 48 percent of the respondent of the sample is comprised by males and females make up 49.3 percent. The studied sample is divided to Health and Nutrition (11.4\%); Rehabilitation (10\%), Pharmacy (10\%), Dentistry (11.8\%), Management and Medical Informatics (13.5\%), Medicine (18.3\%), and Nursing and Midwifery (18.3\%). The main group of the respondents was PhD students (see Table 2). 
Paper-Determinant Factors Affecting the Web-based Training Acceptance by Health Students, Appl...

Table 1. Items used to measure the various constructs in the integrated model

\begin{tabular}{|c|c|c|}
\hline Construct & \begin{tabular}{|c|} 
Item \\
Number
\end{tabular} & Items \\
\hline \multirow{4}{*}{$\begin{array}{l}\text { Perfor- } \\
\text { mance } \\
\text { Expectancy }\end{array}$} & 1 & Using E-learning will help to increase the Efficiency in the work. \\
\hline & 2 & E-learning will help to speed up the learning. \\
\hline & 3 & Electronic medium is suitable to achieve active learning. \\
\hline & 4 & $\begin{array}{l}\text { Electronic environment able us to communicate and interact with the active } \\
\text { scientific community that enhancing the learning. }\end{array}$ \\
\hline \multirow{4}{*}{$\begin{array}{c}\text { Effort } \\
\text { Expectancy }\end{array}$} & 5 & E-learning provides a suitable approach for educators and learners. \\
\hline & 6 & I have clear and understandable interaction with the E-learning medium. \\
\hline & 7 & Using E-learning is convenient. \\
\hline & 8 & It is easy to start E-learning. \\
\hline \multirow{4}{*}{$\begin{array}{c}\text { Attitude } \\
\text { Toward } \\
\text { Technology }\end{array}$} & 9 & I've prefer to use E-learning. \\
\hline & 10 & Using E-learning is associated with joy and passion. \\
\hline & 11 & Using E-learning makes me hopeful. \\
\hline & 12 & Using E-learning helps me to become more active in fulfilling my duties. \\
\hline \multirow{5}{*}{$\begin{array}{l}\text { Social } \\
\text { Influence }\end{array}$} & 13 & University's support on E-learning is adequate. \\
\hline & 14 & Educational system supposes me to use E-learning system. \\
\hline & 15 & Those who influence my characteristics, expect me to use E-learning. \\
\hline & 16 & Using E-learning promotes students' academic position. \\
\hline & 17 & University provides essential conditions for E-learning. \\
\hline \multirow{4}{*}{$\begin{array}{l}\text { Facilitating } \\
\text { Conditions }\end{array}$} & 18 & I have access to the resources needed for E-learning. \\
\hline & 19 & I have enough knowledge to use electronic resources. \\
\hline & 20 & I have a person who supports me as I face E-learning problems. \\
\hline & 21 & E-learning is Compatible in the collaboration with other systems. \\
\hline \multirow{4}{*}{ self-efficacy } & 22 & I am able to organize the electronic files if it's possible to support my activities. \\
\hline & 23 & I can use E-learning in educational affairs if it's possible to support my activities. \\
\hline & 24 & I can use E-learning in educational affairs if I have enough time. \\
\hline & 25 & $\begin{array}{l}\text { I am able to accomplish educational affairs if it's possible to support my activi- } \\
\text { ties. }\end{array}$ \\
\hline \multirow{4}{*}{ anxiety } & 26 & $\begin{array}{l}\text { I am hesitant to use E-learning because of being afraid of not being able to recov- } \\
\text { er my faults. }\end{array}$ \\
\hline & 27 & My interaction with E-learning is clear and understandable. \\
\hline & 28 & Using E-learning is threatening sometimes for me. \\
\hline & 29 & Because of newness and unknowns of the E-learning I feel insecure. \\
\hline \multirow{4}{*}{$\begin{array}{l}\text { Behavioral } \\
\text { Intention }\end{array}$} & 30 & I'm going to use E-learning in future. \\
\hline & 31 & I expect using E-learning could have important progress in learning. \\
\hline & 32 & I expect to use and take profit from E-learning in future. \\
\hline & 33 & Using E-learning in the future is in my schedule. \\
\hline
\end{tabular}


Paper-Determinant Factors Affecting the Web-based Training Acceptance by Health Students, Appl...

Table 2. Demographic information of the sample

\begin{tabular}{|c|c|c|c|c|}
\hline Demographics & Category & Freq. & Per. & Mean \\
\hline & Female & 113 & 49.3 & \\
\hline & Missing & 6 & 2.6 & \\
\hline & Total & 229 & 100 & \\
\hline \multirow{6}{*}{ Age } & $17-21$ & 99 & 43.2 & \multirow{6}{*}{1.6651} \\
\hline & $22-27$ & 92 & 40.2 & \\
\hline & $28-32$ & 21 & 9.2 & \\
\hline & $34 \leq$ & 3 & 1.3 & \\
\hline & Missing & 14 & 6.1 & \\
\hline & Total & 229 & 100 & \\
\hline \multirow{5}{*}{ Degree } & B.S. & 72 & 31.4 & \multirow{5}{*}{2.1244} \\
\hline & M.S. & 46 & 20.1 & \\
\hline & Ph.D. & 99 & 43.2 & \\
\hline & Missing & 12 & 5.2 & \\
\hline & Total & 229 & 100 & \\
\hline \multirow{9}{*}{ faculty } & Medicine & 42 & 18.3 & \multirow{9}{*}{3.7664} \\
\hline & Nursing and Midwifery & 42 & 18.3 & \\
\hline & Health and Nutrition & 26 & 11.4 & \\
\hline & Rehabilitation & 23 & 10 & \\
\hline & Pharmacy & 23 & 10 & \\
\hline & Dentistry & 27 & 11.8 & \\
\hline & Management and Medical Informatics & 31 & 13.5 & \\
\hline & Missing & 15 & 6.6 & \\
\hline & Total & 229 & 100 & \\
\hline
\end{tabular}

In this survey, behavioral intention and user behavior were dependent variables, while PE, EF, SI, FC, ATT, SE, and ANX were independent variables. Results in table showed that there was a statistically significant and positive correlation between all UTAUT variables and the use of E-learning except SI.

Furthermore, Figure 2 illustrates that the model explains about $56 \%$ of the variance (R2=0.56) for using e-learning while PE, EF, SI, FC, ATT, SE, and ANX SI, together, demonstrate about $52 \%$ of the variance for $\mathrm{BI}(\mathrm{R} 2=0.52)$. 
Paper-Determinant Factors Affecting the Web-based Training Acceptance by Health Students, Appl...

Table 3. Correlation between the Variables of the Proposed Conceptual Path Model ${ }^{1,2,3}$

\begin{tabular}{|l|c|c|c|c|c|c|c|c|c|}
\hline Constructs & PE & EE & SI & FC & ATT & SE & ANX & BI & Usage \\
\hline PE & 1 & & & & & & & & \\
\hline EE & $0.366^{* *}$ & 1 & & & & & & & \\
\hline SI & $0.523^{* *}$ & $0.380^{* *}$ & 1 & & & & & & \\
\hline FC & $0.265^{* *}$ & $.0265^{* *}$ & $0.237^{* *}$ & 1 & & & & & \\
\hline ATT & $0.199^{* *}$ & $0.306^{* *}$ & $0.329^{* *}$ & $0.443^{* *}$ & 1 & & & & \\
\hline SE & $0.396^{* *}$ & $0.434^{* *}$ & $0.458^{* *}$ & $0.370^{* *}$ & $0.329^{* *}$ & 1 & & & \\
\hline ANX & $0.379^{* *}$ & $0.311^{* *}$ & $0.253^{* *}$ & $0.249^{* *}$ & $0.178^{* *}$ & $0.238^{* *}$ & 1 & & \\
\hline BI & $0.367^{* *}$ & $0.278^{* *}$ & $0.528^{* *}$ & $0.234^{* *}$ & $0.275^{* *}$ & $0.442^{* *}$ & $0.208^{* *}$ & 1 & \\
\hline Usage & $0.358^{* *}$ & $0.324^{* *}$ & $0.340^{* *}$ & $0.196^{* *}$ & $0.306^{* *}$ & $0.453^{* *}$ & $0.213^{* *}$ & $.0580^{* *}$ & 1 \\
\hline
\end{tabular}

** P-value is significant at 0.01 levels.

* P-value is significant at 0.05 levels.

PE: Performance Expectancy; EE: Effort Expectancy; SI: Social influences; FC: Facilitation condition; ATT: Attitude towards use; SE: Self-Efficacy; ANX: Anxiety; BI: Behavioral intention; Usage : Use of elearning

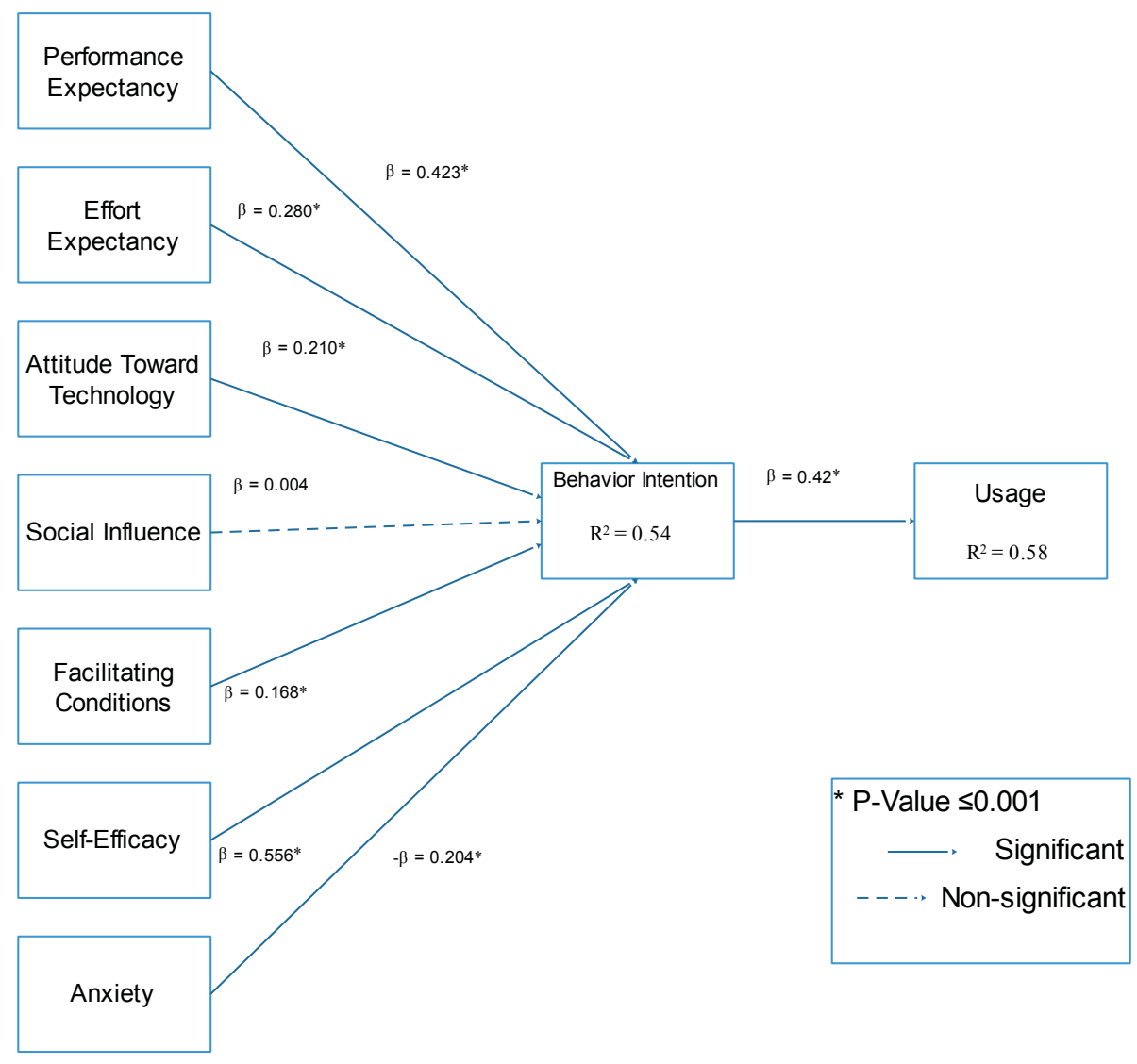

Fig. 2. The results of our UTAUT research model. 
Paper-Determinant Factors Affecting the Web-based Training Acceptance by Health Students, Appl...

\section{Discussion}

The factors influencing the acceptance of web-based training in the Tabriz University of Medical Sciences are analyzed in present study. Despite, the UTAUT model was often used for the web-based training surveys', according to its innovation, we have chosen a quantitative with closed-ended questions due to the being wellorganized feature of theoretical basis to study technology adoption. In addition, it resulted better than its predecessor due to its comprehensive conception of previous technology acceptance models (Venkatesh et al. 2003), thus, we have assumed this.

This study analyzed perspective data combined with objective data from actual in use E-learning systems carefully. It has turned out from results that students of Tabriz University of Medical Sciences (TUOMS) are optimist about web-based learning. Which concludes that student's intention to use E-learning increase as they attend to use it.

The findings indicate that there is statistical significant found between students' Performance Expectancy (PE) and Behavioral Intentions (BI) to use E-learning $(\beta=$. $367, \mathrm{p}<.001)$. And support the results of those of familiar studies Alrawashdeh (2012), Bing tan (2013), Khechine (2014), and Mothibi (2015), M. Abdekhoda, et al (Alrawashdeh, Muhairat, and Alqatawnah 2012, Tan 2013, Khechine et al. 2014, Mothibi 2015). This result had admitted that PE should be considered when universal application of such a system is chased as an important factor.

Due to this study, it is concluded there is statistically relationship between Effort Expectancy of (EE) and Behavioral Intentions (BI) toward use E-learning $(\beta=.278, p$ $<.001)$. According to the EE and BI our findings confirm those of other researchers, Naghavi (2007), Al- Adwan (2013), and Bing tan (2013). Abdekhoda, et al (Naghavi 2007b, Al-Adwan, Al-Adwan, and Smedley 2013, Tan 2013).this means that student expecting E-learning system as user-friendly system; increase their intention to use it.

According to the result of present study, there is a statistical significant connection through the students' Social Influence (SI) on the students' Behavioral Intentions (BI) to use E-learning $(\beta=.528, \mathrm{p}<.001)$, which means that the students encouraged by teachers or someone respectful for them to use E-learning, increase their intention to use them. The results support the findings of previous research Chen (2013), (2013), Sanayei (2013), Bing tan (2013), Khechine (2014), (Yi-Cheng et al. 2013, Tarhini, Hone, and Liu 2013, Tan 2013, Khechine et al. 2014).

Assuming the students Facilitating Conditions (FC) coupled with the Behavioral Intentions (BI), the standard coefficient of $\mathrm{FC}$ and behavioral intention was found to be $(0.234)$ with a p-value of (0.001). The findings are in line with pioneers' research Salari (2009), Jung et al (2010), Sanayei (2013), Chen (2013), Tarhini (2013), Bing $\tan$ (2013), Khechine (2014), Al-rahmi (2015), and in contrast with the Tagoe (2012) and Abdekhoda, et al. (Salari et al. 2009, Jung et al. 2002, SANAYEI and SALIMIAN 2013, Yi-Cheng et al. 2013, Tarhini, Hone, and Liu 2013, Tan 2013, Khechine et al. 2014, Al-rahmi, Othman, and Yusuf 2015, Tagoe 2012). This means providing more facilitating conditions to use E-learning system make students use it more regularly. 
The findings indicate that there is statistical significant found between students' Attitude Toward Technology (ATT) and Behavioral Intentions (BI) to use E-learning $(\beta=.275, p<.001)$, which means that the believe in students that technology is adequet to fulfill their own needs, make them persist on using it. the finding of present investigation agree with previous research Naghavi (2007), Salari (2009), ), Jung et al (2010), Mirzaei (2012), Khorasani (2012), Khademloo (2013), Al- Adwan (2013), As well as this finding is in contrast with the findings of Jahanian (2012) and Karanjam (2015), (Naghavi 2007a, Salari et al. 2009, Jung et al. 2002, Mirzaei, Ahmadipour, and Azizian 2012, Khorasani, Abdolmaleki, and Zahedi 2012, Khademloo et al. 2013, Al-Adwan, Al-Adwan, and Smedley 2013, JAHANIAN and ETEBAR 2012, Karanjam, Kiany Yazdi, and Zarifsanaiey 2015).

According to the result of present study, there is a statistical significant connection through the students' Self-Efficacy (SE) on the students' Behavioral Intentions (BI) to use E-learning $(\beta=0.442, p=0.001)$. This finding confirm the prior findings of Salari (2009), Chen (2013), Tarhini (2013), Sanayei (2013), Al-rahmi (2015), and in contrast with the Hoseyni (2015), and in contrast with the Hoseyni (2015) (Salari et al. 2009, Yi-Cheng et al. 2013, Tarhini, Hone, and Liu 2013, SANAYEI and SALIMIAN 2013, Al-rahmi, Othman, and Yusuf 2015, Hoseyni et al. 2015). This means that their own capabilities are sufficient to accomplish their educational affairs.

Due to this study, it is concluded there is statistically relationship between students' Anxiety (ANX) and Behavioral Intentions (BI) toward use E-learning ( $\beta=$. $208, \mathrm{p}<.001)$. According to the ANX and BI our findings confirm those of other researchers, Taylor (2004), Alenezi (2010), and Chen (2013) (Taylor and Gitsaki 2003, Alenezi, Karim, and Veloo 2010, Yi-Cheng et al. 2013). This finding and those of similar studies have acknowledged the fact that the student's proficiency is improved as a result of confidence reinforced due to effectively reduction of negative effect anxiety because of more comfortable environment provided for students by web-based instruction technology.

Assuming the students Behavioral Intentions (BI) coupled with the actual use of Elearning, the standard coefficient of BI and actual use of E-learning was found to be $(0 \ldots$.$) with a p$-value of $(0.001)$. This finding indicating that if students are persuaded that E-learning is suitable to their course objective, they will apply. And Bing tan (2013), Khechine (2014), and Tandi Lwoga (2014), have same point of view toward discussed advantage.

\section{Conclusion}

In this study, Tabriz University of medical sciences students has been selected as our target sample to study acceptability and E-learning use by means of UTAUT. Its results have provided invaluable insights of technology acceptance in theory and practice, which allowed us to become more informed about the pertaining factors encouraging students to use E-learning. Hence, a specific consideration should be taken into account of satisfying of users. Its verified the meaningful difference have 
Paper-Determinant Factors Affecting the Web-based Training Acceptance by Health Students, Appl...

been seen among their behavioral intention to utilize E-learning. With wider and different samples, future studies could examine UTAUT students.

\section{$8 \quad$ Limitations}

As other studies, this study had some limitations. Firstly, the impact to a set of moderators such as individuals and cultural differences was not analyzed in our study. Secondly, the data collected of TUOMS students by convenience sampling technique does not necessarily represent the all features of university population. This is why generalization of these findings should be treated vigilantly.

\section{Acknowledgments}

This study was supported by TUOMS (Grant NO\# 67698).

\section{Conflict of interest}

The authors declare no conflict of interest

\section{References}

[1] Abdekhoda, Mohammadhiwa, M Ahmadi, A Dehnad, and AF Hosseini. 2014. "Information technology acceptance in health information management." Methods Inf Med 53 (1):14-20. https://doi.org/10.3414/ME13-01-0079

[2] Abdekhoda, Mohammadhiwa, Maryam Ahmadi, Afsaneh Dehnad, Alireza Noruzi, and Mahmodreza Gohari. 2016. "Applying electronic medical records in health care: Physicians' perspective." Applied clinical informatics 7 (2):341. https://doi.org/10.4338/ACI2015-11-RA-0165

[3] Abdekhoda, Mohammadhiwa, Maryam Ahmadi, Mahmodreza Gohari, and Alireza Noruzi. 2015. "The effects of organizational contextual factors on physicians' attitude toward adoption of Electronic Medical Records." Journal of biomedical informatics 53:174-179. https://doi.org/10.1016/j.jbi.2014.10.008

[4] Abdekhoda, Mohammadhiwa, Afsaneh Dehnad, Ghazi Mirsaeed, Sayd Javad, and Vahide Zarea Gavgani. 2016. "Factors influencing the adoption of E-learning in Tabriz University of Medical Sciences." Medical Journal of The Islamic Republic of Iran (MJIRI) 30 (1):1156-1162.

[5] Adams, Dennis A, R Ryan Nelson, and Peter A Todd. 1992. "Perceived usefulness, ease of use, and usage of information technology: A replication." MIS quarterly:227-247.

[6] Al-Adwan, Amer, Ahmad Al-Adwan, and Jo Smedley. 2013. "Exploring students acceptance of e-learning using Technology Acceptance Model in Jordanian universities." International Journal of Education and Development using Information and Communication Technology 9 (2):4. 
Paper-Determinant Factors Affecting the Web-based Training Acceptance by Health Students, Appl...

[7] Al-rahmi, Waleed Mugahed, Mohd Shahizan Othman, and Lizawati Mi Yusuf. 2015. "Exploring the factors that affect student satisfaction through using e-learning in malaysian higher education institutions." Mediterranean Journal of Social Sciences 6 (4):299.

[8] Alenezi, Abdulhameed Rakan, Abdul Malek Abdul Karim, and Arsaythamby Veloo. 2010. "An Empirical investigation into the role of enjoyment, computer anxiety, computer selfefficacy and internet experience in influencing the students' intention to use e-learning: A case study from Saudi Arabian Governmental Universities." TOJET: The Turkish Online Journal of Educational Technology 9 (4).

[9] Alrawashdeh, Thamer A, Mohammad I Muhairat, and Sokyna M Alqatawnah. 2012. "Factors affecting acceptance of web-based training system: using extended UTAUT and structural equation modeling." arXiv preprint arXiv:1205.1904.

[10] AMIRINASAB, $\mathrm{M}$, and A MEHRAZIN. 2014. "COMPARATIVE BETWEEN INNOVATIVE AND ADAPTIVE COGNITIVE MANAGER IN USE \& ERP IMPLEMENTATION."

[11] Andone, L., and NA. Sireteanu. 2009. "Strategies for technology-based learning in higher education." The Fed University, Journal of Higher Education 4 (1):31- 42.

[12] Anthony, LM, MC Clarke, and SJ Anderson. 2000. "Technophobia and personality subtypes in a sample of South African university students." Computers in Human Behavior 16 (1):31-44. https://doi.org/10.1016/S0747-5632(99)00050-3

[13] Asheim, Bjørn, Lars Coenen, and Jan Vang. 2007. "Face-to-face, buzz, and knowledge bases: sociospatial implications for learning, innovation, and innovation policy." Environment and Planning C: Government and Policy 25 (5):655-670. https://doi.org/10.1068/c0648

[14] Babaei, Mahmood 1389. Introduction to E-Learning. 275 vols. Tehran: Pajoheshgah Olom va Fannavarie Iran,

[15] Baron, Reuben M, and David A Kenny. 1986. "The moderator-mediator variable distinction in social psychological research: Conceptual, strategic, and statistical considerations." Journal of personality and social psychology 51 (6):1173. https://doi.org/10.1037/00223514.51.6.1173

[16] Brown, Bettina Lankard. 2014. "Web-Based Training. ERIC Digest No. 218. Brown, Bettina Lankard."

[17] Chen, Chun-Der, Yi-Wen Fan, and Cheng-Kiang Farn. 2007. "Predicting electronic toll collection service adoption: An integration of the technology acceptance model and the theory of planned behavior." Transportation Research Part C: Emerging Technologies 15 (5):300-311. https://doi.org/10.1016/j.trc.2007.04.004

[18] Clarke, Thomas, and Antoine Hermens. 2001. "Corporate developments and strategic alliances in e-learning." Education + Training 43 (4/5):256-267.

[19] Cloete, Elsabé, and Paula Kotzé. 2002. "Reusable and usable environment for the digital courseware domain." Informing Science.

[20] Gillenson, Mark L, and Daniel L Sherrell. 2002. "Enticing online consumers: an extended technology acceptance perspective." Information \& management 39 (8):705-719. https://doi.org/10.1016/S0378-7206(01)00127-6

[21] Govindasamy, Thavamalar. 2001. "Successful implementation of e-learning: Pedagogical considerations." The internet and higher education 4 (3):287-299. https://doi.org/10.1016/S1096-7516(01)00071-9

[22] Hair, Joseph F, William C Black, Barry J Babin, Rolph E Anderson, and Ronald L Tatham. 1998. "Multivariate data analysis . Uppersaddle River." Multivariate Data Analysis (5th ed) Upper Saddle River. 
Paper-Determinant Factors Affecting the Web-based Training Acceptance by Health Students, Appl...

[23] Hamburg, Ileana, and Emma O'Brien. 2014. "Using strategic learning for achieving growth in SMEs." Journal of information technology and application in education 3 (2):77-83. https://doi.org/10.14355/jitae.2014.0302.04

[24] Herrington, Jan, Thomas C Reeves, and Ron Oliver. 2009. A practical guide to authentic e-learning: Routledge.

[25] Hong, SeJoon, James YL Thong, and Kar Yan Tam. 2006. "Understanding continued information technology usage behavior: A comparison of three models in the context of mobile internet." Decision support systems $42 \quad$ (3):1819-1834. https://doi.org/10.1016/j.dss.2006.03.009

[26] Hoseyni, Tayyebeh, Seyyed Saeed Torabi, Nasram Shayan, Mehdi Ismaeel Poor, and Jamal Ashoori. 2015. "Comparing the effects of web-based teaching and cognitive and metacognitive learning strategies on nursing students' academic achievement and selfefficacy, Islamic Azad University, Pishva Branch." Interdisciplinary Journal of Virtual Learning in Medical Sciences (IJVLMS) 6 (2):1-10.

[27] JAHANIAN, RAMEZAN, and SHUKUFE ETEBAR. 2012. "THE EVALUATION OF VIRTUAL EDUCATION IN VIEW POINT VIRTUAL E-LEARNING CENTERS IN UNIVERSITIES OF TEHRAN FROM STUDENTS."

[28] Jung, Insung, Seonghee Choi, Cheolil Lim, and Junghoon Leem. 2002. "Effects of different types of interaction on learning achievement, satisfaction and participation in webbased instruction." Innovations in education and teaching international 39 (2):153-162. https://doi.org/10.1080/14703290252934603

[29] Karanjam, Sara, Farin Kiany Yazdi, and Nahid Zarifsanaiey. 2015. "The comparison of the effect of traditional and off-line electronic educational methods on the knowledge and attitude of the undergraduate dental students of Shiraz University of Medical Sciences." Interdisciplinary Journal of Virtual Learning in Medical Sciences (IJVLMS) 6 (3):20-30.

[30] Khademloo, Mohammad, Ahad Alizade, Hadi Hosseini, Akbar Mohamadi, and Mehdi Fakhar. 2013. "Health and pharmacy students' views about the use of e-learning systems and its related factors." Journal of Mazandaran University of Medical Sciences 22 (2):117-120.

[31] Khechine, Hager, Sawsen Lakhal, Daniel Pascot, and Alphonse Bytha. 2014. "UTAUT model for blended learning: The role of gender and age in the intention to use webinars." Interdisciplinary Journal of E-Learning and Learning Objects 10 (1):33-52. https://doi.org/10.28945/1994

[32] kheirandish, mehdi. 1393. "Expaining model of affecting factors on e-learning effectiveness in post graduate courses." MODIRIATE FANNAVARIE ETTELAAT 6 (4):629-648.

[33] Khorasani, Abasalt, Jamal Abdolmaleki, and Hossein Zahedi. 2012. "Factors affecting ELearning acceptance among students of tehran university of medical sciences based on technology acceptance model (TAM)." Iranian journal of medical education 11 (6):664673.

[34] Liker, Jeffrey K, and Ahmed A Sindi. 1997. "User acceptance of expert systems: a test of the theory of reasoned action." Journal of Engineering and Technology management 14 (2):147-173. https://doi.org/10.1016/S0923-4748(97)00008-8

[35] Liu, Jing. 2013. "E-learning in English classroom: Investigating factors impacting on ESL (English as Second Language) college students' acceptance and use of the Modular ObjectOriented Dynamic Learning Environment (Moodle)."

[36] Luthans, Fred, Bruce J Avolio, James B Avey, and Steven M Norman. 2007. "Positive psychological capital: Measurement and relationship with performance and satisfaction." Personnel psychology 60 (3):541-572. https://doi.org/10.1111/j.1744-6570.2007.00083.x 
Paper-Determinant Factors Affecting the Web-based Training Acceptance by Health Students, Appl...

[37] Mansour, Bassou. 2006. "Challenges and Solutions in Offering Distance Education programs. A case study of an HRD program." International Journal of Instructional Technology \& Distance Learning 2 (11).

[38] Marchewka, Jack T, Chang Liu, and Kurt Kostiwa. 2007. "An application of the UTAUT model for understanding student perceptions using course management software." Communications of the IIMA 7 (2):93.

[39] Mirzaei, M, F Ahmadipour, and F Azizian. 2012. "Viewpoints of students of Shahid Sadoughi University of Medical Sciences towards e-Learning in teaching clinical biochemistry." The Journal of Medical Education and Development 7 (2):67-74.

[40] Mothibi, Gloria. 2015. "A Meta-Analysis of the Relationship between E-Learning and Students' Academic Achievement in Higher Education." Journal of Education and Practice 6 (9):6-9.

[41] Naghavi, M. A.Seyde. 2007a. "Study of Teachers and Students Attitude toward Elearning:Surveying in Iran's E-learning Universities." Quarterly Journal of Research and Planning in Higher Education 13 (1):157-176.

[42] Naghavi, MA. 2007b. "Study of Teachers and Students Attitude toward E-learning: Surveying in Iran's E-learning Universities." Quarterly journal of research and planning in higher education 13 (1):157-176.

[43] Nigg, Claudio R, Sonia Lippke, and Jason E Maddock. 2009. "Factorial invariance of the theory of planned behavior applied to physical activity across gender, age, and ethnic groups." Psychology of Sport and Exercise 10 (2):219-225. https://doi.org/10.1016/j.psychsport.2008.09.005

[44] Njenga, James Kariuki, and Louis Cyril Henry Fourie. 2010. "The myths about e- learning in higher education." British journal of educational technology 41 (2):199-212. https://doi.org/10.1111/j.1467-8535.2008.00910.x

[45] Pikkarainen, Tero, Kari Pikkarainen, Heikki Karjaluoto, and Seppo Pahnila. 2004. "Consumer acceptance of online banking: an extension of the technology acceptance model." Internet research 14 (3):224-235. https://doi.org/10.1108/10662240410542652

[46] Rosenberg, Marc Jeffrey. 2001. E-learning: Strategies for delivering knowledge in the digital age. Vol. 3: McGraw-Hill New York.

[47] Salari, MOHAMMAD MAHDI, FARIDEH Yaghmaei, S Mehdizade, ZOHREH Vafadar, and M Afzali. 2009. "Factors related to accept of" e-learning" in nursing students." $E d u$ cation Strategies in Medical Sciences 2 (3):103-108.

[48] SANAYEI, A, and H SALIMIAN. 2013. "THE ANALYSIS OF EFFECTING FACTORS ON VIRTUAL EDUCATION ACCEPTANCE WITH EMPHASIS ON INTERNAL FACTORS."

[49] Sherry, Lorraine. 1996. "Issues in distance learning." International journal of educational telecommunications 1 (4):337-365.

[50] Sohrabiyourtchi, B., M. Mosakhani, S. Shafia, and H. R. Yazdani. 2010. "Identify the factors influencing the formation of student satisfaction." Management vision 9 (3): 39-61.

[51] Song, Sung Mi. 2010. "E-learning: Investigating students' acceptance of online learning in hospitality programs."

[52] Tagoe, Michael. 2012. "Students' Perceptions on Incorporating E-Learning into Teaching and Learning at the University of Ghana." International Journal of Education and Development using Information and Communication Technology 8 (1):91-103.

[53] Tan, Paul Juinn Bing. 2013. "Applying the UTAUT to understand factors affecting the use of English e-learning websites in Taiwan." Sage Open 3 (4):2158244013503837. https://doi.org/10.1177/2158244013503837 
Paper-Determinant Factors Affecting the Web-based Training Acceptance by Health Students, Appl...

[54] Tarhini, Ali, Kate Hone, and Xiaohui Liu. 2013. "User acceptance towards web-based learning systems: Investigating the role of social, organizational and individual factors in European higher education." Procedia Computer Science 17:189-197. https://doi.org/10.1016/j.procs.2013.05.026

[55] Taylor, R, and Christina Gitsaki. 2003. "Teaching WELL and loving IT." New perspectives on CALL for second language classrooms:131-147.

[56] Venkatesh, Viswanath, Michael G Morris, Gordon B Davis, and Fred D Davis. 2003. "User acceptance of information technology: Toward a unified view." MIS quarterly:425-478.

[57] Weil, Michelle M, and Larry D Rosen. 1995. "The psychological impact of technology from a global perspective: A study of technological sophistication and technophobia in university students from twenty-three countries." Computers in Human Behavior 11 (1):95-133. https://doi.org/10.1016/0747-5632(94)00026-E

[58] Yi-Cheng, CHEN, LIN Yi-Chien, Ron Chuen Yeh, and LOU Shi-Jer. 2013. "Examining factors affecting college students' intention to use web-based instruction systems: Towards an integrated model." Tojet: the turkish online journal of Educational Technology 12 (2).

[59] Zikmund, W. 2003. Business research methods 7th ed., Thomson/South-Western. Appendices.

\section{Authors}

Asghar Sattari is MSc. student of Medical library and information sciences. School of health management and medical informatics. Tabriz University of medical sciences. Tabriz, Iran.

Mohammadhiwa Abdekhoda is $\mathrm{PhD}$, Assistance professor in health information management. Iranian Center of Excellence in Health Management (IceHM). School of Management and Medical Informatics. Tabriz University of Medical Sciences, Tabriz, Iran. (Abdekhodam@tbzmed.ac.ir)

Vahideh Zarea Gavgani PhD, Associated professor in health information management. Department of medical library and information sciences. School of health management and medical informatics. Tabriz University of medical sciences. Tabriz, Iran.

Article submitted 07 June 2017. Published as resubmitted by the authors 20 september 2017. 